\title{
Contemporary Hindi Films: A Tool for Women Empowerment
}

\author{
Sushila Shekhawat ${ }^{1 *}$ and Neerja Vyas ${ }^{2}$
}

\begin{abstract}
Innumerable shades of women have found representation in various media formats such as television, print media, social media, internet, cinema etc. Fight for equality and more prominently human rights has been taken up by several prominent film makers to bring this pertinent issue to the limelight so as to enlighten the masses by exposing the actual story of women being involved. This paper tries to study depiction of women in selected Indian Films to better explore their role in shaping up new perspectives on gender equality playing a significant role in sensitizing people towards the reality associated with the issues. The study would also try to look at the different projections and filmic images which have dared to go beyond the conventional portrayal and created a new identity of the empowered women with examples from films like Fire, Pink, Gulaab gang, Kahaani, etc.
\end{abstract}

\section{KEYWORDS}

Media; Equality; Cinema; Women Empowerment; Hindi Films

Representations through different media formats have always proved as catalysts for social change due to their immense potential in influencing and shaping the attitudes, opinions and perception of the masses. Media has played a significant role in bringing to the fore the existing reality of the status of women and its changing paradigms. It is

\footnotetext{
${ }^{1}$ Department of Humanities and Social Sciences, Birla Institute of Technology and Science (BITS), Pilani, India

2 Department of Languages, Manipal University Jaipur, India

*Corresponding author;

Email: sula@pilani.bits-pilani.ac.in
}

a well-argued fact that issues such as inequality, considering them inferior and incapable especially in relation to their male counterparts was and is still an impediment in their progression as individuals in different sections of the society.

Women empowerment in its myriad manifestations have been dealt with by the different forms of media such as Broadcasting media, print media, social media, digital media, internet, etc. wherein Cinema enjoys the status of the most widely accessible medium in almost all the different types of media. This paper attempts to study the representation of women in Indian Films so as to understand their role in shaping up new perspectives on gender equality and also sensitizing people towards the reality associated with the issues. In films dealing with feministic issues a very well framed questions are being posed related to their role in filmic narration, placement in the entire narrative in comparison to other prominent characters, etc.

On closer introspection, we get to know the impact of films as there are films which have dared to go beyond the conventional portrayal and created a new identity of the empowered women. However, despite being key players in the development of the nation, there are films which do not treat Women at par with the male counterparts and their role is a marginalized one in some of the films. To illustrate the multifaceted images in Indian Hindi films, Examples have been drawn from earlier films like Fire, Mother India and the recent ones like Pink, Gulaab Gang, Kahaani etc. Such films have proved to be a major milestone in setting up new trends in showcasing issues relevant to women and have come across as eye-openers for the masses and therefore are an intriguing area of study. 
Films being indispensable cultural tools of social change hold an important place in the social milieu in bringing change in the mindset of the people regarding established practices and values. Fight for equality and more prominently human rights has been taken up by several film makers so as to bring the issue to the limelight and also to enlighten the masses in exposing the actual story of women being involved. As said, the representation of women in cinema has been a major issue of debate amongst feminist film theorists in India. The complex and fascinating relationship between women and cinema has a substantial literature and some interesting work on third world feminism, which illuminates aspects of the representation of women in Indian films. The representation of women and the representation by women on screen are essential for understanding the interplay between women and cinema in India (Gokulsing and Dissanayake, 1998).

Films are cultural signifiers and hence wield an enormous power to deeply influence our perceptions, our sensibilities with specific reference to the culture and the society we are living in. Moreover, Cinema influences an individual's behaviour, perception and position in his culture and society and hence encompasses all the multifaceted aspects integral to society. The issue of projection of women also occupies a unique place in cinema (Shekhawat, 2009). As a medium with the strongest influence on the Indian psyche, we explore through these portrayals how cinema has played an important role in promoting a new empowered identity of Indian women through recent shifts in its content of production.

Laura Mulvey says that, "Men act, women appear. Men look at women; women watch themselves being looked at", this quote suggests very succinctly the position of women in the realm of the 'look'. In Indian cinema, women have been relegated to the passive position in film after film, as "bearer, not the maker of meaning", merely an appendage to the man, the wielder of power. (Mulvey, 1998, p. 384)
Initially women were portrayed as timid, docile and vulnerable in Indian cinema. Woman was usually considered a homemaker surviving under the protective shield of her husband. However strong female roles have their main reliance on mainly the vamps in the films though the present delineation has undergone a rapid change. In the past, Cinema was mostly dominated by males on the celluloid due to their significant presence in the entire filmmaking arena and as usual off the celluloid due to the societal norms. Presently women can be seen in multifaceted roles and share a position of parity in the changing scenario of Indian cinema. A complete shift can be observed in the delineation of women portrayal through films and the women characters now are more balanced, decisive and powerful.

There have been revolutionary films like Duniya Na Maane, Chetna, etc but Mother India is a quintessential film which has gained a stature of a legend in Indian Cinema. Remarkable in its representation of showcasing the highly dignified image without succumbing to the clutches of poverty is a noteworthy aspect. This film has set a tone for the future generation filmmakers to project woman in a lead role having all the essential attributes hitherto considered integral to her male counterpart.

Aandhi is one such film which has incorporated the same ideological concept in its theme and treatment. Bhumika is yet another filmic mode to establish the irresistible desire of a female to lead a life on her own terms. The character is bold enough not to remain confined to the space allotted by her husband, but in her quest for love, happiness and self-identity keeps on shunting between so many males in her life and face the challenges boldly. In a society where relationships are measured from the point of view of man, when a woman decides to mould the norm, she ends up being lonely. Trying to figure out who she is and what she is, his protagonist Usha finds herself trapped in unequal relationships only to be told towards the end 'beds change, men don't'. It rings a bell more than three decades 
after "Bhumika" hit the theatres. (The Hindu, 2014)

The same self-sufficient image of woman gets highlighted in the film Arth where actress Shabana Azmi has played the role of a selfsufficient woman ready to embark on a journey without any help. Despite her husband's extra marital affair and his decision of leaving her, she has the courage to move forward in life. Another film Fire from the trilogy of Deepa Mehta shatters the stereotypes about women, and questions the patriarchal mindset that seeks to control even the sexuality of women. With powerful dialogues and subtleties which an observant viewer is expected to catch on, the movie succeeds in having a profound effect on the viewers' minds.

Many critics argue that the movie only tackles one facet of oppression, that with regard to sexuality. Noted Indian feminist authors Mary E. John and Tejaswini Niranjana wrote in 1999 that Fire reduces patriarchy to the denial and control of female sexuality. "Control of female sexuality is surely one of the ideological planks on which patriarchy rests. But by taking this idea literally, the film imprisons itself in the very ideology it seeks to fight ... 'Fire' ends up arguing that the successful assertion of sexual choice is ...indeed, the sole criterion-for the emancipation of women."

Emergence of strong women characters has been a distinguishing character of the last two decades in both the mainstream as well as offbeat ranging from Mirch Masala, Mandi, Sardari Begum and Mrityudand to Lajja, Astitva, Chandni Bar, Pinjar, Chameli, Satta, Dor and many others. Despite the fact that they were not highly popular they managed to creep into the well-defined coterie of patriarchal set up. There have been many upheavals in the entire journey of female oriented films wherein the action era heroines have not been depicted as very strong and rational and heroes were more powerful. Moreover, they were just represented as being shy, meek, dancing around the trees, without any important role in the film but even in that scenario one film Mirch Masala directed by Ketan Mehta in 1989, hit the theatres with a powerful message and became a trendsetter in showing the collective struggle of women as an entity.

With the recent changes in the filmmaking scenario, there have been films wherein women have been designated roles not just as sex symbols and side characters but the main lead responsible to move the story forward. Hence it can be observed that a woman is not just in the process of empowerment on the screen in her roles but has also occupied a prominent place as a director and producer as well.

The film "Pink", is a recently released powerful and brave Hindi mainstream film which focuses on young women who in the course of their everyday struggle has to face innumerable issues related to their survival and instead of avoiding. they themselves come up with the solutions to deal with such issues in a bold and realistic way. This tendency of the present generation not to avoid but coming to terms with the problem is an area worth appreciating for women across the world.

It can be said that it has taken a long time for Bollywood filmmakers to communicate such a bold message through realistic characters and projection which hint towards the prevailing status quo in the society and the country we live in and the social mores that its women have had to abide by as a part of prevalent patriarchy. Another film "Parched" is quite acclaimed because of its realistic depictions and giving a ray of hope for the coming change. The spirit of the film is celebrating fights against an unjust system and society and emerging winners - not because they have well-intentioned men rescuing them, but because they can save themselves. Parched is a women-centric film and revolves around three ordinary women, from rural areas of Rajasthan, where women are still considered as weaker sex. It not only showcases the trials and tribulations that rural women have to face in those places, but also highlights how men perceive their women. 
Similar film "Gulaab Gang" has also helped demystify and elucidate the stark reality of the struggle that backward class women have to face in Indian villages and towns even today, through its projections of strong women who stand up for themselves and refuse to take any wrong at the hands of the patriarchal society.

To highlight the fierce shade in women, the film "Mardaani" by Rani Mukherjee is an apt example in which her role is actually very challenging and with aplomb handles cases of child trafficking. An amalgamation of beauty and brains, she acts as a source of motivation. The perfect mix of strength and respect, her character acts as an inspiration for the entire women community.

Another noteworthy performance by Rani Mukherjee is as Meera Gaity, an aggressive Journalist in the film "No One Killed Jessica" whose honesty towards her profession is exemplary and whose irresistible urge to fight against injustice enables a victim to get justice. She not only single-handedly reopened the case but also got the public involved and finally gave the much-needed closure to the family of the innocent girl who was murdered. Gaity is the perfect example of a modern, empowered woman who can bring a larger change.

The portrayal of the boxer Mary Kom by Priyanka Chopra is yet another influential female role in the history of Indian cinema. The entire story of this world champion stands as a testimony for everyone who wants to dream and convert his dream into reality. In India, such films act as a perfect motivational symbol where to take up sports as a career for women is considered not a very favourable sign. The exemplary success of the film serves as a great inspiration and motivation for all women who due to their social conditioning think their career would take a setback when they get married or embrace motherhood.

Kahaani is another path breaking film which is a story of a woman who fails to trace her missing husband and, in her journey, courageously encounters all odds and is able to solve the mystery. The story emphasizes the immense power that a woman can exhibit and how can she subvert the stereotypical image of woman.

Such bold and convincing portrayals and the contemporary approach of filmmaking thus becoming women-centric definitely speaks up for the changing societal conditions and the awareness of the people about the prevalent ills and at the same time audience acceptance and appreciation of the unconventional works indicates that they are ready to fight for the rights of the women and challenge the status.

\section{REFERENCES}

Gokulsing K. M., and Dissanayake W. 1998, 'Indian Popular Cinema: A Narrative of Cultural Change'. London: Trentham Books Limited.

Goswami P. 2016, 'Parched review round-up: Here is what critics have to say about Radhika Apte's film', International Business Times, Retrieved from $<$ http://www.ibtimes.co.in/parched-review-roundhere-what-critics-have-say-about-radhika-aptes-film694625>

Gupta S. 2016, 'Pink movie review: A blazing indictment of all that's wrong with us', Indian Express, Retrieved from

$<$ http://indianexpress.com/article/entertainment/mo vie-review/pink-movie-review-amitabh-bachchantaapsee-pannu-star-rating-3032180/>

Kaushal S. 2016, 'Parched review: Where women celebrate struggles and emerge winners', Hindustan Times, Retrieved from

$<$ http://www.hindustantimes.com/moviereviews/parched-review-where-women-celebratestruggles-and-emerge-winners/storyxU5TFUp70v5rJKTwKPFEjK.html> Kumar A. 2014, 'Bhumika (1977)', The Hindu, Retrieved from http://www.thehindu.com/features/fridayreview/bhumika-1977/article6221624.ece> Mulvey, L. 1999, 'Visual Pleasure and Narrative Cinema', [ed.] Leo Braudy and Marshall Cohen. Film Theory and Criticism. New York: Oxford University Press, 1999.

Pandolin, 2016, 'Ladies Special: Changing Role of Women in Hindi Cinema, Retrieved from http://pandolin.com/ladies-special-changing-rolewomen-hindi-cinema/

Pareek S. 2015, '11 Powerful Women Characters In Indian Cinema That Show What Women Can Truly 
Achieve', The Better India, Retrieved from

http://www.thebetterindia.com/18586/11-powerfulwomen-characters-indian-cinema-show-women-cantruly-achieve/>

Ramachandran N. 2014, 'Indian Audiences Embracing Women-Centric Films', Variety, Retrieved from $<$ http://variety.com/2014/film/asia/indian-audiencesembracing-women-centric-films-1201180875/>

Sastry K. 2015, 'Comparing Bollywood's Portrayal of Women From Past To Present, India.com, Retrieved from http://www.india.com/arts-andculture/comparing-bollywoods-portrayal-of-womenfrom-past-to-present-164384/> Shekhawat, S., 2009, 'Portrayal of Females in Indian English Feminist Fiction and Hindi Parallel Cinema during 1975-2005'. Ph.D Thesis, Retrieved from: Shodhganga $<$ http://shodhganga.inflibnet.ac.in/jspui/bitstream/10 603/123790/2/thesis sr2003phxf416 final.doc.> Times of India 2016, 'Women-centric films to look forward to in 2016', Retrieved from http://timesofindia.indiatimes.com/entertainment/hi ndi/bollywood/news/Women-centric-films-to-lookforward-to-in-2016/articleshow/50466030.cms> 